\title{
Elite Controllers and Long-term Nonprogressors: Models for HIV Vaccine Development?
}

Jason F. Okulicz*

Infectious Disease Service, San Antonio Military Medical Center, San Antonio TX, USAngeles, CA 90027, USA

\begin{abstract}
Elite controllers and Long-term nonprogressors (LTNP) are uncommon subgroups of HIV-infected individuals that are typically associated with improved clinical outcomes compared to other members of the HIV-infected population. These groups have particularly desirable characteristics for developing a therapeutic vaccine for HIV infection, namely spontaneous virologic suppression in elite controllers and prolonged elevation in CD4 cell counts in LTNP. Despite these favorable characteristics, some individuals in these groups experience HIV disease progression including virologic escape, CD4 decline, and the development of AIDS and serious non-AIDS events. Due to the heterogeneity observed in these populations, it is essential to select individuals with durable virologic control and/or CD4 cell count trajectories when considering elite controllers and LTNP as models for development of therapeutic vaccines.
\end{abstract}

\section{Introduction}

The pathogenesis of HIV infection involves the depletion of CD4+ T-cells resulting in immunodeficiency. For the vast majority of patients infected with HIV, ongoing viral replication and CD4 cell count declines eventually lead to the development of acquired immune deficiency syndrome (AIDS) and ultimately death in the absence of antiretroviral therapy (ART). Elite controllers are a subset of HIV-infected persons who have the ability to spontaneously control plasma viral load without ART. Although defined by virologic criteria, typically the presence of serial viral load measurements below the limit of detection for prolonged periods, elite controllers are also associated with elevated CD4 cell counts and reduced risk of AIDS and death [1]. Elite controllers comprise a very small subgroup with most HIV cohorts reporting a prevalence of $<1 \%[1,2]$. Despite the rarity of this phenotype, elite controllers are being aggressively studied to determine the mechanisms responsible for spontaneous virologic control with the hope of developing novel treatment strategies and perhaps even a therapeutic vaccine to treat patients infected with HIV.

In contrast to the virologic criteria used to define elite controllers, long-term nonprogressors (LTNP) are classically defined as having prolonged elevation in CD4 cell counts for many years in the absence of ART. This immunologic-based phenotype, first recognized in the preART era, consists of an uncommon subset of HIV-infected individuals with most studies reporting a prevalence of 2-15\% [1,3-5]. With widespread availability of viral load testing after the mid 1990s, most LTNP were found to have low to moderate levels of viremia $[3,6-8]$. Despite differing definitions, an exceedingly rare group of individuals can be characterized by both elite controller and LTNP definitions. For example, the U.S. Military HIV Natural History Study and SEROCO/ HEMOCO cohorts demonstrated that the percentage of LTNP also meeting elite controller criteria was $4 \%$ and $12 \%$, respectively $[1,3]$. This review highlights the utility of studying these uncommon HIV phenotypes as potential models for vaccine development, with a particular emphasis on the study of elite controllers due to the expanding knowledge and interest in this phenotype.

\section{Elite Controllers and LTNP: Variability of Definitions}

The identification of well-characterized phenotypes is essential when considering elite controllers and LTNP as models for vaccine development. The lack of uniformity in the literature for defining both elite controllers and LTNP represents a potential pitfall for studying these groups. For example, elite controllers typically have undetectable viral loads, but there have been differences in the limit of detection for viral load assays over the past decade. Thus, an elite controller defined by viral load $<400$ copies $/ \mathrm{mL}$ may not be similar to another defined by viral load $<20$ copies $/ \mathrm{mL}$. The duration of virologic control may also differ [1,9-12]. Similarly for LTNP, there are differences in the magnitude and possibly the slope of CD4 counts over time $[1,3,13$ 15]. These differences in elite controller and LTNP definitions used in the literature are summarized in Table 1 . Due to the variability of definitions and follow-up time in elite controller and LTNP cohorts, it is paramount to select patients with durability of these phenotypes, particularly the duration of spontaneous virologic control in elite controllers.

\section{Elite Controllers and LTNP as Models for Functional Cure of HIV Infection}

The term "functional cure" is typically defined as the ability to achieve persistent control of HIV infection without the need for treatment such as ART. Elite controllers and LTNP often have desirable characteristics that warrant consideration as potential models for functional cure. Elite controllers typically have undetectable viral loads which is a current treatment goal for patients on ART [16]. The goal of achieving undetectable viral load by means other than ART is an important goal for vaccine development. The mechanisms leading to spontaneous virologic control have not been fully described; however recent data suggests low $\mathrm{T}$ cell regulatory responses may be involved

*Corresponding author: Jason F. Okulicz, MD, Brooke Army Medical Center, 3551 Roger Brooke Drive, Fort Sam Houston, TX 78234-6200, USA, Tel: (210) 916-4355; Fax: (210) 916-5900; E-mail: Jason.okulicz@amedd.army.mil

Received January 04, 2012; Accepted January 27, 2012; Published January 31 2012

Citation: Okulicz JF (2012) Elite Controllers and Long-term Nonprogressors: Models for HIV Vaccine Development? J AIDS Clinic Res 3:139. doi:10.4172/21556113.1000139

Copyright: (C) 2012 Okulicz JF. This is an open-access article distributed under the terms of the Creative Commons Attribution License, which permits unrestricted use, distribution, and reproduction in any medium, provided the original author and source are credited. 
Citation: Okulicz JF (2012) Elite Controllers and Long-term Nonprogressors: Models for HIV Vaccine Development?. J AIDS Clinic Res 3:139. doi:10.4172/2155-6113.1000139

\begin{tabular}{|c|c|c|c|}
\hline Characteristic & Elite Controllers & $\begin{array}{l}\text { Long-term Nonpro- } \\
\text { gressors }\end{array}$ & Comments \\
\hline $\begin{array}{l}\text { Magnitude of viral } \\
\text { load }\end{array}$ & $\begin{array}{l}\text { Typically below the } \\
\text { limit of detection of } \\
\text { the clinical assay } \\
\text { (i.e. }<50 \text { copies } / \mathrm{mL} \text { ) }\end{array}$ & $\mathrm{N} / \mathrm{A}$ & $\begin{array}{l}\text { Low to moderate } \\
\text { viremia is com- } \\
\text { mon in LTNP }\end{array}$ \\
\hline $\begin{array}{l}\text { Longitudinal char- } \\
\text { acteristics of viral } \\
\text { load suppression }\end{array}$ & $\begin{array}{l}\text { Varying definitions: } \\
\text { a) } \geq 3 \text { undetect- } \\
\text { able VLs over } \geq 12 \\
\text { months }[1,9] \\
\text { b) Undetectable VLs } \\
\text { for } \geq 2 \text { years [11] } \\
\text { c) }>90 \% \text { with unde- } \\
\text { tectable VLs for } \geq 10 \\
\text { years [12] }\end{array}$ & N/A & \\
\hline $\begin{array}{l}\text { Magnitude of CD4 } \\
\text { cell count }\end{array}$ & N/A & $\begin{array}{l}\geq 500 \text { cells/uL most } \\
\text { common }\end{array}$ & $\begin{array}{l}\text { CD4 cell counts } \\
\text { typically elevated } \\
\text { in elite controllers }\end{array}$ \\
\hline $\begin{array}{l}\text { Longitudinal char- } \\
\text { acteristics of CD4 } \\
\text { cell count }\end{array}$ & N/A & $\begin{array}{l}\text { Varying definitions: } \\
\text { a) All CD4 counts } \\
\geq 600 \text { cells/uL for } \\
\geq 7 \text { years [13] } \\
\text { a) All CD4 values } \\
\geq 500 \text { cells/uL for } \\
\geq 8 \text { years [3] } \\
\text { b) All CD4 values } \\
\geq 500 \text { cells/L for } \\
\geq 10 \text { years [1] } \\
\text { c) Definitions } \\
\text { including both } \\
\text { magnitude and } \\
\text { slope of CD4 over } \\
\text { time [14,15] }\end{array}$ & \\
\hline $\begin{array}{l}\text { Antiretroviral } \\
\text { therapy }\end{array}$ & No therapy & No therapy & \\
\hline $\begin{array}{l}\text { AIDS-defining } \\
\text { illness }\end{array}$ & Absent & Absent & \\
\hline
\end{tabular}

Table 1: Variability of Definitions in the Literature for Elite Controllers and Longterm Nonprogressors.

[17]. Although the presence of defective HIV virus was considered a possible contributor to elite controller status, several studies have shown recovery of replication-competent virus $[18,19]$.

Although formerly termed "aviremic controllers", many elite controllers have detectable virus with one longitudinal study showing that only 6 of 11 elite controllers had a viral load $<1$ copy/mL with serial measurements during follow-up [20]. It is unclear whether a proportion of elite controllers are persistently $<1 \mathrm{copy} / \mathrm{mL}$ or if all elite controllers have detectable virus by single-copy assay at some point during the course of untreated HIV infection. Interestingly, a French study showed that elite controllers with transient low-level viremia, termed "blips", do not experience CD4 declines compared to those who do not have detectable viremia [21]. In contrast to elite controllers, LTNP are typically viremic by standard clinical viral load assays. Since viremic individuals are more likely to transmit HIV to seronegative sexual contacts [22], this distinction has important public health implications.

Elite controllers are not defined by CD 4 criteria and may experience CD4 declines over time and eventually require ART [23]. AIDS events have also been described in elite controllers, either by CD4 criteria or development of AIDS-defining events such as Kaposi sarcoma and pulmonary tuberculosis [1,24]. The determinants of CD4 decline in elite controllers have not been fully characterized. Although HIV infection typically causes immunodeficiency, there is also persistent inflammation and activation of the immune system which may have many detrimental effects including cardiovascular disease, renal dysfunction, neurocognitive decline, liver failure, and osteoporosis [25]. Elite controllers have been shown to have a greater magnitude of immune activation compared to those with suppressed viral load on ART [24]. Despite this finding, however, one study showed that $\mathrm{T}$ cell activation was not a driver of CD4 decline in elite controllers [26]. Since HIV is a chronic inflammatory disease, the development of a therapeutic vaccine that can reduce immune activation as well as reduce plasma viremia would be highly advantageous.

LTNP have prolonged, stable elevation in CD4 cell counts which is also characteristic of patients on ART. Although some LTNP may have a potential disadvantage of low to moderate level viremia, CD4 stability is an important outcome for vaccine research. Viral load-independent mechanisms are likely involved in determining CD4 slope, with one study demonstrating that steady state viral load contributes only $4 \%$ towards CD4 decline [27]. Conversely, it also appears that the magnitude of CD4 cell count does not determine virologic control. A recent study in macaque elite controllers showed that reduction of CD4 cells in vivo did not affect viral load [28]. Thus, it is attractive to pursue vaccine strategies aimed at attaining durable CD4 cell counts and stable trajectories but such an approach may not impact plasma viral load.

\section{Host and Immunologic Factors Associated with Elite Controllers and LTNP}

Specific demographic characteristics, such as age, race, gender, and mode of HIV transmission, have not been observed in elite controllers and LTNP $[1,3,20]$. There have been a number of host genetic and immunologic characteristics reported, particularly in the more extensively studied elite controller population. Protective MHC class I alleles, including HLA B57 and B27 containing the Bw4 motif, are overrepresented in elite controllers $[10,12,29]$. In European and North American cohorts, HLA B5701 is enriched while HLA B5703 is observed with greater frequency in those of African descent [19,30,31]. Although studies have shown enrichment for these protective alleles, some elite controllers lack these alleles suggesting they are not necessarily required for host virologic control. Similarly, CCR5 Delta 32 gene deletion has been reported in only a small proportion of LTNP and elite controllers [30,32-34].

There is evidence suggesting that an adaptive MHC class I-restricted CD8-mediated control is operating, given the linkage between the MHC class I locus and elite controllers [9,35-37]. Strong CD8 responses to HIV-gag are often reported in elite controllers with subsequent production of cytotoxic granules, IL-2 and IFN-g, and cell surface expression of CD27 leading to high functional avidity [35,37-39]. CD8 cells also demonstrate antiviral effects by inhibiting virus production from super-infected CD4 cells in elite controllers [36,38]. The intense cell-mediated response to HIV infection has not been demonstrated in all elite controllers suggesting that other viral control mechanisms are in effect $[9,40]$. Other possible mechanisms may include innate immunity mediated by natural killer cells, as evidenced by the strong association of KIR3DL1 allele in HLA B57 positive individuals [4143]. Neutralizing antibodies have not been shown to have a major role, as these antibodies may be nearly absent in some elite controllers $[10,44,45]$ and perhaps have a positive correlation with viral load as reported in studies involving LTNP [46,47]. Also, some studies of broadly neutralizing antibodies in elite controllers have shown these antibodies to contain a narrow spectrum of activity $[48,49]$. 
Citation: Okulicz JF (2012) Elite Controllers and Long-term Nonprogressors: Models for HIV Vaccine Development?. J AIDS Clinic Res 3:139. doi:10.4172/2155-6113.1000139

Page 3 of 4

\section{Elite Controllers and LTNP as Models of Vaccine Design}

Both elite controllers and LTNP exhibit a high degree of heterogeneity in many different areas, including demographic characteristics, host genetics, immunologic characteristics, rates of HIV disease progression and clinical outcomes, and even by criteria used in the literature to define these groups. Each phenotype possesses a desirable target for vaccine development: virologic suppression in elite controllers and stable, elevated CD4 cell counts for prolonged periods in LTNP. As previously discussed, the overlapping population meeting criteria for both elite controllers and LTNP is exceedingly rare. However, this combined phenotype likely represents the most advantageous approach for vaccine development research in these groups since this combined phenotype has a greater number of desirable characteristics than the singular elite controller and LTNP phenotypes. Due to the stability and durability inherent in a combined definition, this combination elite controller/LTNP phenotype has also been proposed in the literature [50]. In particular, the trait of spontaneous virologic control demonstrated in elite controllers is of lesser value if HIV disease progression occurs despite a suppressed viral load. It is also likely that viral load-independent mechanisms are involved in the magnitude and maintenance of CD 4 cell counts. Thus, a vaccine aimed to accomplish both virologic suppression and CD4 stability may not be feasible and single approaches targeting either viral load suppression or CD4 maintenance may be preferred.

In summary, elite controllers and LTNP represent uncommon subgroups of the HIV-infected population that are typically associated with improved clinical outcomes. However, lack of HIV disease progression and both AIDS and serious non-AIDS outcomes can also occur in these populations. The heterogeneous nature of these groups poses significant challenges for vaccine development. Well-defined and characterized phenotypes are necessary if elite controllers and/or LTNP are to be considered as a potential model for vaccine development.

\section{Conflict of Interest}

The content of this publication is the sole responsibility of the author and does not necessarily reflect the views or policies of the Department of Defense or the Departments of the Army, Navy or Air Force.

\section{References}

1. Okulicz JF, Marconi VC, Landrum ML, Wegner S, Weintrob A, et al. (2009) Clinical outcomes of elite controllers, viremic controllers, and long-term nonprogressors in the US Department of Defense HIV natural history study. J Infect Dis 200: 1714-1723.

2. Grabar S, Selinger-Leneman H, Abgrall S, Pialoux G, Weiss L, et al. (2009) Prevalence and comparative characteristics of long-term nonprogressors and HIV controller patients in the French Hospital Database on HIV. AIDS 23: 11631169.

3. Madec Y, Boufassa F, Avettand-Fenoel V, Hendou S, Melard A, et al. (2009) Early control of HIV-1 infection in long-term nonprogressors followed since diagnosis in the ANRS SEROCO/HEMOCO cohort. J Acquir Immune Defic Syndr 50: 19-26.

4. Munoz A, Kirby AJ, He YD, Margolick JB, Visscher BR, et al. (1995) Long-term survivors with HIV-1 infection: incubation period and longitudinal patterns of CD4+ lymphocytes. J Acquir Immune Defic Syndr Hum Retrovirol 8: 496-505.

5. Sheppard HW, Lang W, Ascher MS, Vittinghoff E, Winkelstein W (1993) The characterization of non-progressors: long-term HIV-1 infection with stable CD4+ T-cell levels. AIDS 7: 1159-1166.

6. Lefrere JJ, Morand-Joubert L, Mariotti M, Bludau H, Burghoffer B, et al. (1997) Even individuals considered as long-term nonprogressors show biological signs of progression after 10 years of human immunodeficiency virus infection 90: $1133-1140$.

7. O'Brien TR, Blattner WA, Waters D, Eyster E, Hilgartner MW, et al. (1996)
Serum HIV-1 RNA levels and time to development of AIDS in the Multicenter Hemophilia Cohort Study. JAMA 276: 105-110.

8. Rodes B, Toro C, Paxinos E, Poveda E, Martinez-Padial M, et al. (2004) Differences in disease progression in a cohort of long-term non-progressors after more than 16 years of HIV-1 infection. AIDS 18: 1109-1116.

9. Deeks SG, Walker BD (2007) Human immunodeficiency virus controllers: mechanisms of durable virus control in the absence of antiretroviral therapy Immunity 27: 406-416.

10. Pereyra F, Addo MM, Kaufmann DE, Liu Y, Miura T, et al. (2008) Genetic and immunologic heterogeneity among persons who control HIV infection in the absence of therapy. J Infect Dis 197: 563-571.

11. Riedel DJ, Sajadi MM, Armstrong CL, Cummings JS, Cairo C, et al. (2009) Natural viral suppressors of HIV-1 have a unique capacity to maintain gammadelta T cells. AIDS 23: 1955-1964.

12. Lambotte O, Boufassa F, Madec Y, Nguyen A, Goujard C, et al. (2005) HIV controllers: a homogeneous group of HIV-1-infected patients with spontaneous control of viral replication. Clin Infect Dis 41: 1053-1056.

13. Pantaleo G, Menzo S, Vaccarezza M, Graziosi C, Cohen OJ, et al. (1995 Studies in subjects with long-term nonprogressive human immunodeficiency virus infection. N Engl J Med 332: 209-216.

14. Strathdee SA, Veugelers PJ, Page-Shafer KA, McNulty A, Moss AR, et al. (1996) Lack of consistency between five definitions of nonprogression in cohorts of HIV-infected seroconverters. AIDS 10: 959-965.

15. Buchbinder S, Vittinghoff E (1999) HIV-infected long-term nonprogressors: epidemiology, mechanisms of delayed progression, and clinical and research implications. Microbes Infect 1: 1113-1120.

16. Thompson MA, Aberg JA, Cahn P, Montaner JS, Rizzardini G, et al. (2010) Antiretroviral treatment of adult HIV infection: 2010 recommendations of the International AIDS Society-USA panel. JAMA 304: 321-333

17. Hunt PW, Landay AL, Sinclair E, Martinson JA, Hatano H, et al. (2011) A low $T$ regulatory cell response may contribute to both viral control and generalized immune activation in HIV controllers. PLoS One 6: e15924.

18. Blankson JN, Bailey JR, Thayil S, Yang HC, Lassen K, et al. (2007) Isolation and characterization of replication-competent human immunodeficiency virus type 1 from a subset of elite suppressors. J Virol 81: 2508-2518.

19. Kiepiela P, Ngumbela K, Thobakgale C, Ramduth D, Honeyborne I, et al. (2007) CD8+ T-cell responses to different HIV proteins have discordant associations with viral load. Nat Med 13: 46-53.

20. Pereyra F, Palmer S, Miura T, Block BL, Wiegand A, et al. (2009) Persisten low-level viremia in HIV-1 elite controllers and relationship to immunologic parameters. J Infect Dis 200: 984-990.

21. Boufassa F, Saez-Cirion A, Lechenadec J, Zucman D, Avettand-Fenoel V, et al (2011) CD4 dynamics over a 15 year-period among HIV controllers enrolled in the ANRS French observatory. PLoS One 6: e18726.

22. Cohen MS, Chen YQ, McCauley M, Gamble T, Hosseinipour MC, et al. (2011) Prevention of HIV-1 infection with early antiretroviral therapy. N Engl J Med 365: 493-505.

23. Okulicz JF, Grandits GA, Weintrob AC, Landrum ML, Ganesan A, et al. (2010) CD4 $\mathrm{T}$ cell count reconstitution in HIV controllers after highly active antiretroviral therapy. Clin Infect Dis 50: 1187-1191.

24. Hunt PW, Brenchley J, Sinclair E, McCune JM, Roland M, et al. (2008) Relationship between T cell activation and CD4+ T cell count in HIV-seropositive individuals with undetectable plasma HIV RNA levels in the absence of therapy. J Infect Dis 197: 126-133.

25. Phillips AN, Neaton J, Lundgren JD (2008) The role of HIV in serious diseases other than AIDS. AIDS 22: 2409-2418.

26. Kamya P, Tsoukas CM, Boulet S, Routy JP, Thomas R, et al. (2011) T cell Activation does not drive CD4 decline in longitudinally followed HIV-infected Elite Controllers. AIDS Res Ther 8: 20

27. Dolan MJ, Kulkarni H, Camargo JF, He W, Smith A, et al. (2007) CCL3L1 and CCR5 influence cell-mediated immunity and affect HIV-AIDS pathogenesis via viral entry-independent mechanisms. Nat Immunol 8: 1324-1336.

28. Mudd PA, Ericsen AJ, Price AA, Wilson NA, Reimann KA, et al. (2011) 
Citation: Okulicz JF (2012) Elite Controllers and Long-term Nonprogressors: Models for HIV Vaccine Development?. J AIDS Clinic Res 3:139. doi:10.4172/2155-6113.1000139

Reduction of CD4+ T cells in vivo does not affect virus load in macaque elite controllers. J Virol 85: 7454-7459.

29. Migueles SA, Sabbaghian MS, Shupert WL, Bettinotti MP, Marincola FM, et al. (2000) HLA B ${ }^{\star} 5701$ is highly associated with restriction of virus replication in a subgroup of HIV-infected long term nonprogressors. Proc Natl Acad Sci USA 97: $2709-2714$

30. Pereyra F, Jia X, McLaren PJ, Telenti A, de Bakker PI, et al. (2010) The major genetic determinants of HIV-1 control affect HLA class I peptide presentation. Science 330: 1551-1557.

31. Han Y, Lai J, Barditch-Crovo P, Gallant JE, Williams TM, et al. (2008) The role of protective HCP5 and HLA-C associated polymorphisms in the control of HIV-1 replication in a subset of elite suppressors. Aids 22: 541-544.

32. Carrington M, Nelson GW, Martin MP, Kissner T, Vlahov D, et al. (1999) HLA and HIV-1: heterozygote advantage and $\mathrm{B}^{\star} 35-\mathrm{CW}^{*} 04$ disadvantage. Science 283: $1748-1752$

33. Kaslow RA, Carrington M, Apple R, Park L, Muñoz A, et al. (1996) Influence of combinations of human major histocompatibility complex genes on the course of HIV-1 infection. Nat Med 2: 405-411.

34. Magierowska M, Theodorou I, Debre P, Sanson F, Autran B, et al. (1999) Combined genotypes of CCR5, CCR2, SDF1, and HLA genes can predict the long-term nonprogressor status in human immunodeficiency virus-1-infected individuals. Blood 93: 936-941.

35. Almeida JR, Price DA, Papagno L, Arkoub ZA, Sauce D, et al. (2007) Superior control of HIV-1 replication by CD8+ T cells is reflected by their avidity, polyfunctionality, and clonal turnover. J Exp Med 204: 2473-2485.

36. Saez-Cirion A, Lacabaratz C, Lambotte O, Versmisse P, Urrutia A, et al. (2007) HIV controllers exhibit potent CD8 T cell capacity to suppress HIV infection ex vivo and peculiar cytotoxic T lymphocyte activation phenotype. Proc Natl Acad Sci U S A 104: 6776-6781.

37. Xie J, Lu W, Samri A, Costagliola D, Schnuriger A, et al. (2010) Distinct differentiation profiles of HIV-Gag and Nef-specific central memory CD8+ T cells associated with HLA-B57/5801 and virus control. Aids 24: 2323-2329.

38. Migueles SA, Osborne CM, Royce C, Compton AA, Joshi RP, et al. (2008) Lytic granule loading of CD8+ T cells is required for HIV-infected cell elimination associated with immune control. Immunity 29: 1009-1021.

39. Almeida JR, Sauce D, Price DA, Papagno L, Shin SY, et al. (2009) Antigen sensitivity is a major determinant of CD8+ T-cell polyfunctionality and HIVsuppressive activity. Blood 113: 6351-6360.
40. Saez-Cirion A, Sinet M, Shin SY, Urrutia A, Versmisse P, et al. (2009) Heterogeneity in HIV suppression by CD8 T cells from HIV controllers: association with Gag-specific CD8 T cell responses. J Immunol 182: 78287837.

41. Alter G, Martin MP, Teigen N, Carr WH, Suscovich TJ, et al. (2007) Differential natural killer cell-mediated inhibition of HIV-1 replication based on distinct KIR/ HLA subtypes. J Exp Med 204: 3027-3036.

42. Alter G, Rihn S, Walter K, Nolting A, Martin M, et al. (2009) HLA class I subtypedependent expansion of KIR3DS1+ and KIR3DL1+ NK cells during acute human immunodeficiency virus type 1 infection. J Virol 83: 6798-6805.

43. Martin MP, Qi Y, Gao X, Yamada E, Martin JN, et al. (2007) Innate partnership of HLA-B and KIR3DL1 subtypes against HIV-1. Nat Genet 39: 733-740.

44. Lambotte O, Ferrari G, Moog C, Yates NL, Liao HX, et al. (2009) Heterogeneous neutralizing antibody and antibody-dependent cell cytotoxicity responses in HIV-1 elite controllers. Aids 23: 897-906.

45. Bailey JR, Lassen KG, Yang HC, Quinn TC, Ray SC, et al. (2006) Neutralizing antibodies do not mediate suppression of human immunodeficiency virus type 1 in elite suppressors or selection of plasma virus variants in patients on highly active antiretroviral therapy. J Virol 80: 4758-4770.

46. Braibant M, Brunet S, Costagliola D, Rouzioux C, Agut H, et al. (2006) Antibodies to conserved epitopes of the HIV-1 envelope in sera from long-term non-progressors: prevalence and association with neutralizing activity. Aids 20 1923-1930.

47. Ngo-Giang-Huong N, Candotti D, Goubar A, Autran B, Maynart M, et al. (2001) HIV type 1-specific IgG2 antibodies: markers of helper T cell type 1 response and prognostic marker of long-term nonprogression. AIDS Res Hum Retroviruses 17: 1435-1446.

48. Scheid JF, Mouquet H, Feldhahn N, Seaman MS, Velinzon K, et al. (2009) Broad diversity of neutralizing antibodies isolated from memory B cells in HIVinfected individuals. Nature 458: 636-640.

49. Doria-Rose NA, Klein RM, Manion MM, O'Dell S, Phogat A, et al. (2009) Frequency and phenotype of human immunodeficiency virus envelope-specific B cells from patients with broadly cross-neutralizing antibodies. J Virol 83: 188 199.

50. Migueles SA, Connors M (2010) Long-term nonprogressive disease among untreated HIV-infected individuals: clinical implications of understanding immune control of HIV. JAMA 304: 194-201. 